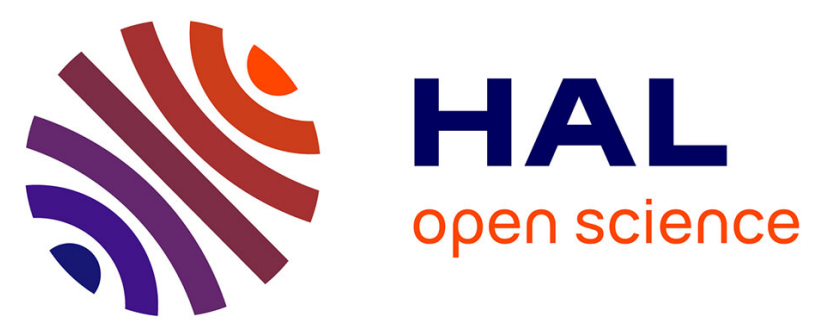

\title{
Water-soluble naphthalimide-based 'Pourbaix sensors': pH and redox-activated fluorescent AND logic gates based on photoinduced electron transfer
}

\author{
Alex D. Johnson, Kyle A. Paterson, Jake C. Spiteri, Sergey A. Denisov,
} Gediminas Jonusauskas, Arnaud A Tron, Nathan D. Mcclenaghan, David C. Magri

\section{To cite this version:}

Alex D. Johnson, Kyle A. Paterson, Jake C. Spiteri, Sergey A. Denisov, Gediminas Jonusauskas, et al.. Water-soluble naphthalimide-based 'Pourbaix sensors': $\mathrm{pH}$ and redox-activated fluorescent AND logic gates based on photoinduced electron transfer. New Journal of Chemistry, 2016, 40 (12), pp.9917 - 9922. 10.1039/C6NJ02023B . hal-01426556

\section{HAL Id: hal-01426556 https://hal.science/hal-01426556}

Submitted on 4 Jan 2017

HAL is a multi-disciplinary open access archive for the deposit and dissemination of scientific research documents, whether they are published or not. The documents may come from teaching and research institutions in France or abroad, or from public or private research centers.
L'archive ouverte pluridisciplinaire HAL, est destinée au dépôt et à la diffusion de documents scientifiques de niveau recherche, publiés ou non, émanant des établissements d'enseignement et de recherche français ou étrangers, des laboratoires publics ou privés.

\section{다(1)(2)}

Distributed under a Creative Commons Attribution - ShareAlikel 4.0 International 


\title{
Water-soluble naphthalimide-based 'Pourbaix sensors': pH and redox-activated fluorescent AND logic gates based on photoinduced electron transfer
}

\author{
Alex D. Johnson, ${ }^{a}$ Kyle A. Paterson, ${ }^{a}$ Jake C. Spiteri, ${ }^{a}$ Sergey A. Denisov, ${ }^{b}$ \\ Gediminas Jonusauskas, ${ }^{c}$ Arnaud Tron, ${ }^{b}$ Nathan D. McClenaghan ${ }^{\mathrm{b}}$ and \\ David C. Magri*a
}

\begin{abstract}
Two novel naphthalimide-based 'Pourbaix sensors' for redox potential and $\mathrm{pH}$ were designed based on a 'fluorophore-spacer ${ }_{1}-$ receptor-spacer ${ }_{2}$-electron-donor' configuration. The synthesised molecular logic gates consist of an alkylated 1,8-naphthalimide fluorophore connected to a tertiary amine by a flexible ethylene spacer to a ferrocene moiety via a methylene spacer. The UV-visible absorption and steady state fluorescent properties were examined in methanol and 1:1 (v/v) methanol/water. The spectroscopic properties are modulated by internal charge transfer (ICT) and photoinduced electron transfer (PET) mechanisms. A $\log \beta_{\mathrm{H}^{+}}$of 9.2 and 8.7 were determined in $1: 1(\mathrm{v} / \mathrm{v})$ methanol/water for the methylated 1 and butylated 2 compounds, respectively. An apparent $\log \beta_{\mathrm{Fe}^{3+}}$ of 4.2 was determined in $1: 1(\mathrm{v} / \mathrm{v}) \mathrm{methanol} /$ water at $\mathrm{pH}$ 4. Time-resolved spectroscopic studies elucidated the stimulus-modulated photoinduced electron transfer pathways. In the oxidised and protonated state, 1 exhibits a single fluorescence lifetime of 8.5 ns, while an efficient photoinduced electron transfer characterised by a time constant of 20 ps is revealed by femtosecond transient absorption spectroscopy in the absence of a perturbing stimulus.
\end{abstract}

\section{Introduction}

The development of photoinduced electron transfer (PET) sensors and switches, which began as curiosity-based science, ${ }^{1}$ is now state-of-the-art technology used in screening catalytic reactions, ${ }^{2}$ detecting chemical warfare agents, ${ }^{3}$ and measuring blood analyte ${ }^{4}$ and glucose $e^{5}$ levels. The basic concept is the engineering of molecules in a modular format according to a 'fluorophorespacer-receptor' configuration. ${ }^{6}$ The modular construction is amenable to modifications with respect to both format and functionalities. $^{7}$ The predictable modulation of the luminescence has been further exploited to create switchable molecular systems with two or more states that emulate familiar electronic devices such as logic gate circuits ${ }^{8}$ and triodes. ${ }^{9}$ Recently we proposed a new class of photo-redox-ionic logic gates termed

\footnotetext{
${ }^{a}$ Department of Chemistry, Faculty of Science, University of Malta, Msida, MSD 2080, Malta. E-mail: david.magri@um.edu.mt

${ }^{b}$ Institut des Sciences Moléculaires, CNRS UMR 5255, University of Bordeaux, 33405 Talence, France.E-mail: nathan.mcclenaghan@u-bordeaux.fr

${ }^{c}$ Laboratoire Ondes et Matières d'Aquitaine, CNRS UMR 5798,

University of Bordeaux, 33405 Talence, France
}

'Pourbaix sensors'. ${ }^{10}$ This class of molecular logic gate integrates the 'fluorophore-spacer-receptor' motif with a 'fluorophorespacer-electron-donor' design. ${ }^{11}$ Our first examples consisted of a 'fluorophore-spacer ${ }_{1}$-receptor-spacer ${ }_{2}$-electron-donor' arrangement (Fig. 1) with a central anthracene fluorophore. ${ }^{10}$ With the aim of improving water solubility and the fluorescence enhancement ratio, among other properties, we recently designed a molecular device with the structurally unsymmetrical naphthalimide fluorophore based on a 'receptor-spacer ${ }_{1}-$ fluorophore-spacer $_{2}$ electron-donor' format. ${ }^{12}$

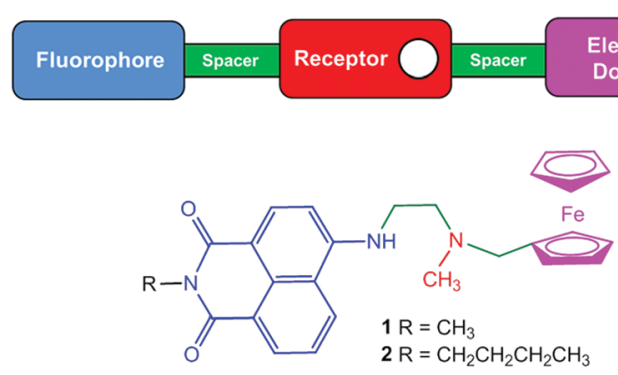

Fig. 1 A schematic diagram of a 'fluorophore-spacer ${ }_{1}-$ receptorspacer $_{2}$-electron-donor' design and the molecular structures of $\mathbf{1}$ and $\mathbf{2}$. 
Naphthalimides are a remarkable class of fluorophore due to a strong internal charge transfer (ICT) character, which results in a large dipole moment in the excited state and an intense photoelectric field effect. ${ }^{13}$ Depending on the magnitude and sign of the generated electric field, intramolecular photoinduced electron transfer can be either inhibited or accelerated. Due to the presence of this intrinsic phenomenon, we were interested in exploring the potential of naphthalimide-based 'Pourbaix sensors' with a 'fluorophore-spacer ${ }_{1}$-receptor-spacer ${ }_{2}$-electrondonor.' In addition, this design is amenable to the incorporation of an anchoring/linking unit at the imide position ( $\mathrm{R}$ group) for covalent immobilisation to surfaces. ${ }^{4,14}$

The relationship between $\mathrm{pH}$ and potential $(\mathrm{pE})$ has long been known to be paramount to our fundamental understanding of metal ion solubility in geology, metallurgy and medicine. ${ }^{15} \mathrm{We}$ envision that molecular devices responsive to $\mathrm{pH}$ and redox chemistry could have a multitude of future state-of-the-art applications from corrosion detection, ${ }^{16}$ histochemistry, ${ }^{17}$ blood disorder diagnostics ${ }^{18}$ to anticancer agents. ${ }^{19}$ In fact, research is on-going to develop $\mathrm{pH}$ and redox-responsive micelles as intracellular drug delivery systems ${ }^{20}$ and photodynamic photosensitizers. ${ }^{21}$

We now report two novel fluorescent molecular AND logic gates modulated by redox potential and $\mathrm{pH}$ in aqueous methanol solution. 'Pourbaix sensors' $\mathbf{1}$ and $\mathbf{2}$ consist of an alkylated 1,8-naphthalimide (fluorophore) connected to a tertiary amine (proton receptor/electron donor) by a flexible ethylene spacer, the amine being linked by a methylene spacer to a ferrocene moiety (electron donor). The different alkyl spacers are deliberately incorporated into the design allowing for conformational mobility. An enhanced fluorescence output is observed upon simultaneous protonation of the tertiary amine with acid and oxidation of the ferrocene moiety with a suitable oxidant, in this study $\mathrm{Fe}^{3+}$.

\section{Results and discussion}

The naphthalimide-based logic gates $\mathbf{1}$ and $\mathbf{2}$ were prepared by a three-step procedure (Scheme 1). Condensation of methylamine with the anhydride precursor in tetrahydrofuran (THF) followed by amination with $N$-methylethylenediamine yielded 4- $N$-methylethylenediamine-1,8- $N$-methylnaphthalimide in $45 \%$ yield as the protonated salt. The final synthetic step involved reductive amination with ferrocenecarboxaldehyde and sodium triacetoxyborohydride in 1,2-dichloroethane (DCE) in the presence of triethylamine to give 1 in $20 \%$ yield. Purification was achieved by column chromatography and recrystallisation (see Experimental section). The 'Pourbaix sensors' $\mathbf{1}$ and $\mathbf{2}$ were characterised by ${ }^{1} \mathrm{H}$ and ${ }^{13} \mathrm{C}$ NMR, IR and HRMS (Fig. S1-S6, ESI $\dagger$ ).

The UV-visible absorption spectra were measured in 1:1 (v/v) methanol/water and neat methanol solutions. Broad structureless absorption bands are observed with maxima at $439 \mathrm{~nm}$ and $440 \mathrm{~nm}$ in methanol, and at $446 \mathrm{~nm}$ and $450 \mathrm{~nm}$ in 1:1 (v/v) methanol/water for $\mathbf{1}$ and 2, respectively. Addition of acid $\left(10^{-3} \mathrm{M}\right)$ to a solution of 1 results in hypsochromic shifts of $19 \mathrm{~nm}$ and $16 \mathrm{~nm}$ to maxima at $420 \mathrm{~nm}$ and $430 \mathrm{~nm}$ in $1: 1(\mathrm{v} / \mathrm{v})$ methanol/water and methanol with no change in the absorption
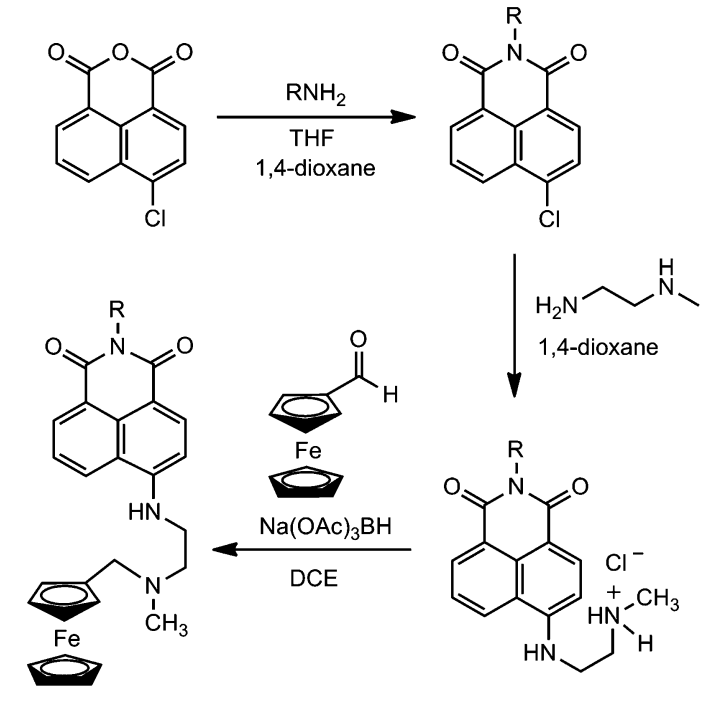

$1 \mathrm{R}=\mathrm{CH}_{3}$

$2 \mathrm{R}=\mathrm{CH}_{3} \mathrm{CH}_{2} \mathrm{CH}_{2} \mathrm{CH}_{2}$

Scheme 1 The synthesis of 'Pourbaix sensors' 1 and 2.

intensity. Similarly, 2 exhibits hypsochromic shifts of $c a .18 \mathrm{~nm}$. Isosbestic points are observed at $438 \mathrm{~nm}$ and $437 \mathrm{~nm}$ in $1: 1(\mathrm{v} / \mathrm{v})$ methanol/water for 1 and 2, respectively (Fig. S7 and S9, ESI $\dagger$ ). The addition of acid results in the formation of a less stable FrankCondon charge transfer excited state on protonation of the tertiary amine at the 4-position. ${ }^{22}$ Intramolecular hydrogen bonding between the protonated tertiary amine and the $\mathrm{NH}$ amine and/ or an electrostatic field effect could contribute to the destabilization of the ICT state. The addition of more than $80 \mu \mathrm{M} \mathrm{Fe} e^{3+}$ significantly perturbs the UV-visible absorbance intensity (Fig. S8 and S10, ESI $\dagger$ ). The photophysical data of 1 and 2 as well as $3^{12}$ (Scheme 2) are provided in Table 1.

The Boolean logic characteristics of $\mathbf{1}$ and $\mathbf{2}$ were examined in $1: 1(\mathrm{v} / \mathrm{v})$ methanol/water and methanol. The molecules display a fluorescence enhancement accompanied by a hypsochromic shift of $14 \mathrm{~nm}$ on addition of high threshold concentration levels of $\mathrm{H}^{+}$and $\mathrm{Fe}^{3+}$. Three 'off' states are ascribed to an ICT and/or PET from either the ferrocene moiety and/or the tertiary amine to the excited state naphthalimide fluorophore. Table 2 summarizes the AND logic truth table including the relative fluorescence quantum yields $\left(\Phi_{\mathrm{f}}\right)$ of $\mathbf{1}$ and 2 .

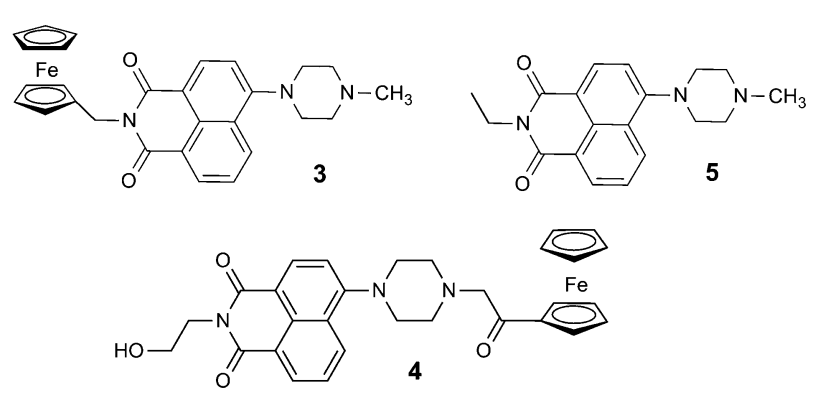

Scheme 2 Naphthalimide-based 'Pourbaix sensors' $\mathbf{3}$ and $\mathbf{4}$ and ferrocenefree model 5. 
Table 1 Summary of various photophysical parameters of $\mathbf{1 - 3}$ determined by UV-visible absorption and steady-state fluorescence spectroscopy ${ }^{a}$

\begin{tabular}{|c|c|c|c|c|c|c|}
\hline & $\begin{array}{l}\mathbf{1} \\
\mathrm{MeOH}\end{array}$ & $\begin{array}{l}1 \\
\mathrm{H}_{2} \mathrm{O} / \mathrm{MeOH}\end{array}$ & $\begin{array}{l}2 \\
\mathrm{MeOH}\end{array}$ & $\begin{array}{l}2 \\
\mathrm{H}_{2} \mathrm{O} / \mathrm{MeOH}\end{array}$ & $\begin{array}{l}3 \\
\mathrm{MeOH}\end{array}$ & $\begin{array}{l}3 \\
\mathrm{H}_{2} \mathrm{O} / \mathrm{MeOH}\end{array}$ \\
\hline$\lambda_{\mathrm{AbspH} 12}{ }^{b}$ & 439 & 446 & 440 & 450 & 399 & 405 \\
\hline $\log \varepsilon_{\mathrm{pH} 12}{ }^{c}$ & 4.25 & 4.22 & 4.28 & 4.26 & 4.10 & 4.04 \\
\hline$\lambda_{\mathrm{AbspH} 3}$ & 420 & 430 & 422 & 432 & 378 & 386 \\
\hline $\log \varepsilon_{\mathrm{pH} 3}{ }^{c}$ & 4.23 & 4.22 & 4.27 & 4.32 & 4.12 & 4.08 \\
\hline$\lambda_{\text {Isos }} / \mathrm{nm}$ & 433 & 438 & 432 & 437 & 390 & 399 \\
\hline$\lambda_{\mathrm{Flu}} / \mathrm{nm}$ & 527 & 526 & 530 & 535 & 521 & 525 \\
\hline$\Delta \lambda / \mathrm{nm}^{e}$ & 107 & 96 & 108 & 103 & 143 & 139 \\
\hline $\mathrm{p} \beta_{\mathrm{H}^{++*}} f$ & nd & 9.2 & 9.9 & 8.7 & nd & 6.6 \\
\hline
\end{tabular}

${ }^{a} 4 \pm 1 \mu \mathrm{M}$ 1-3 in $\mathrm{MeOH}$ or $1: 1(\mathrm{v} / \mathrm{v}) \mathrm{MeOH} / \mathrm{H}_{2} \mathrm{O}$ solutions. Some data for 3 is originally reported in ref. $12 .{ }^{b}$ Basic $\mathrm{pH}$ adjusted with $0.1 \mathrm{M}$ $\mathrm{NaOH}$; values in $\mathrm{nm} .{ }^{c}$ Molar absorptivity $\varepsilon$ in $\mathrm{L} \mathrm{mol}^{-1} \mathrm{~cm}^{-1}$. ${ }^{d}$ Acidic $\mathrm{pH}$ adjusted with $\mathrm{CH}_{3} \mathrm{SO}_{3} \mathrm{H}$; values in nm. ${ }^{e} \Delta \lambda$ taken as the Stokes shift between the absorption and fluorescence spectra at $\mathrm{pH} 3$ in presence of $50 \mu \mathrm{M} \mathrm{Fe}^{3+} .{ }^{f}$ Determined by $\log \left[\left(I_{\max }-I\right) /\left(I-I_{\min }\right)\right]=-\log \left[\mathrm{H}^{+}\right]+\log \beta_{\mathrm{H}^{+}}$ from fluorescence emission spectra. Fluorescence emission spectra obtained by excitation at $\lambda_{\text {Isos }}$. nd $=$ not determined.

Table 2 Truth table of AND logic gate $\mathbf{1}$ and $\mathbf{2}^{\mathrm{a}}$

\begin{tabular}{llll}
\hline $\begin{array}{l}\text { Input } \\
\left(\mathrm{H}^{+}\right)^{d}\end{array}$ & $\begin{array}{l}\text { Input }_{2} \\
\left(\mathrm{Fe}^{3+}\right)^{e}\end{array}$ & $\begin{array}{l}\text { Output emission } \\
\mathbf{1}^{b}\left(\Phi_{\mathrm{f}}\right)^{f}\end{array}$ & $\begin{array}{l}\text { Output emission } \\
\mathbf{2}^{c}\left(\Phi_{\mathrm{f}}\right)^{f}\end{array}$ \\
\hline 0 (low) & 0 (low) & 0 (low, 0.001) & 0 (low, 0.012) \\
1 (high) & 0 (low) & 0 (low, 0.008) & 0 (low, 0.017) \\
0 (low) & 1 (high) & 0 (low, 0.001) & 0 (low, 0.012) \\
1 (high) & 1 (high) & 1 (high, 0.040) & 1 (high, 0.050)
\end{tabular}

${ }^{a} 10^{-5} \mathrm{M} 1$ excited at the isosbestic point of $438 \mathrm{~nm}$ and $432 \mathrm{~nm} .{ }^{b} 1: 1$ $(\mathrm{v} / \mathrm{v}) \mathrm{MeOH} / \mathrm{H}_{2} \mathrm{O} .{ }^{c} \mathrm{MeOH} .{ }^{d}$ High input level $10^{-6.0} \mathrm{M}$ methanesulfonic acid. Low input level $10^{-11.0} \mathrm{M}$. ${ }^{e}$ High input level $70 \mu \mathrm{M}$ iron(III) sulfate pentahydrate. Low input level in absence of added iron(III). ${ }^{f}$ Relative $\Phi_{\mathrm{f}}$ measured with reference to $10^{-7} \mathrm{M}$ fluorescein in $0.1 \mathrm{M} \mathrm{NaOH}$ aerated water $\left(\Phi_{\mathrm{f}}=0.91\right)$. Digital threshold limit set at $\Phi_{\mathrm{f}}>0.025$.

The Weller equation was used to predict the theoretical feasibility for the PET pathways. ${ }^{23}$ The singlet energy from the intersection of the excitation and emission spectra at $468 \mathrm{~nm}$ is $2.55 \mathrm{eV}$ in $1: 1(\mathrm{v} / \mathrm{v})$ methanol/water. ${ }^{24}$ The calculated driving forces for PET from the tertiary amine and ferrocene to the excited state naphthalimide are $0.07 \mathrm{eV}$ and $-0.63 \mathrm{eV}$, respectively. These calculations suggest that PET from ferrocene to the excited state fluorophore should be highly favorably, while PET/ICT from the amine to the naphthalimide is sluggish. However, a repulsive negative field effect at the imide nitrogen atom is an additional kinetic barrier for PET from ferrocene to the naphthalimide as with 3 , which is not accounted for in the driving force calculation. ${ }^{13}$ On the opposite end, a positive electric field effect at the 4-amino position contributes to enhance the rate of PET from the tertiary amine to the naphthalimide.

The 'Pourbaix sensors' $\mathbf{1}$ and $\mathbf{2}$ display some definite advantages over our previous anthracene prototypes ${ }^{10}$ including a longer emission maxima and solubility in aqueous methanol. The $\Phi_{\mathrm{f}}$ of 1 and $\mathbf{2}$ in the 'on' state is significantly higher than in the three 'off' states in both methanol and 1:1 (v/v) methanol/water (Table 2, entry 4). The switching ratio between the maximum and second highest fluorescence output is on average a four-fold enhancement. Compared to AND logic gate 3 with an alternative arrangement consisting of an 'electron-donor-spacer ${ }_{1}$ fluorophore-spacer ${ }_{2}$-receptor', the maximum $\Phi_{\mathrm{f}}$ of $\mathbf{1}$ and $\mathbf{2}$ and fluorescence switching ratios are lower, but no less significant. ${ }^{12}$ Our results are similar to some extent to a related molecule 4 with a rigid piperazine bridge connecting a carboxyferrocene by a methylene spacer (Scheme 2). ${ }^{25}$ The $\Phi_{\mathrm{f}}$ of 4 is 0.091 on oxidation of the carboxyferrocene moiety in acetonitrile. Upon protonation of the piperazine moiety the $\Phi_{\mathrm{f}}$ is 0.38 . However, the simultaneous oxidation and protonation of $\mathbf{4}$ in accordance to the function of an AND logic gate was not reported. ${ }^{25}$ The similarity in the output response ratio of $\mathbf{4}$ suggests that $\mathbf{1}$ and $\mathbf{2}$ adopt a conformation such that the ferrocene moiety is distant from the naphthalimide fluorophore. Coincidentally, the same platform was incorporated into a three-input INHIBIT logic gate. ${ }^{26}$ Nonetheless, clear digital switching between the 'off' states and the green fluorescent 'on' state of $\mathbf{1}$ and $\mathbf{2}$ is distinguishable with the naked eye (Fig. 2a and Fig. S11, ESI $\dagger$ ).

Fluorimetric titration experiments were performed in 1:1 (v/v) methanol/water and methanol solution. The proton concentration in $1: 1(\mathrm{v} / \mathrm{v})$ methanol/water was monitored with a calibrated $\mathrm{pH}$ meter, while titrations in methanol were performed by adding aliquots of known acid concentration. An increase in the $\left[\mathrm{H}^{+}\right]$resulted in sigmoidal-shaped profiles between $\mathrm{pH} 10$ and 7 followed by a plateau region till $\mathrm{pH} 3$ (Fig. S15, ESI $\dagger$ ). Fitting of the data to the equation $\log \left[\left(I_{\max }-I\right) /\left(I-I_{\min }\right)\right]=-\log \left[\mathrm{H}^{+}\right]+\log \beta_{\mathrm{H}^{+}}$ yields a $\log \beta_{\mathrm{H}^{+}}$of 9.2 and 8.7 for 1 and 2 , respectively, in $1: 1(\mathrm{v} / \mathrm{v})$ methanol/water (Fig. S12-S15, ESI $\dagger$ ). The $\log \beta_{\mathrm{H}^{+}}$of 2 in methanol was found to be an order of magnitude higher (Table 1 and Fig. S16, S17, ESI $\dagger$ ). An apparent $\log \beta_{\mathrm{Fe}^{3+}}$ of 4.2 was determined for 1 in $1: 1(\mathrm{v} / \mathrm{v})$ methanol/water at $\mathrm{pH} 4$.

Time-resolved fluorescence spectroscopy was used to measure the fluorescence lifetimes of $\mathbf{1}$ and $\mathbf{3}$ under the four logic states in $1: 1(\mathrm{v} / \mathrm{v})$ methanol/water. At $\mathrm{pH} 11$, where complete deprotonation is anticipated, and hence fully quenched emission
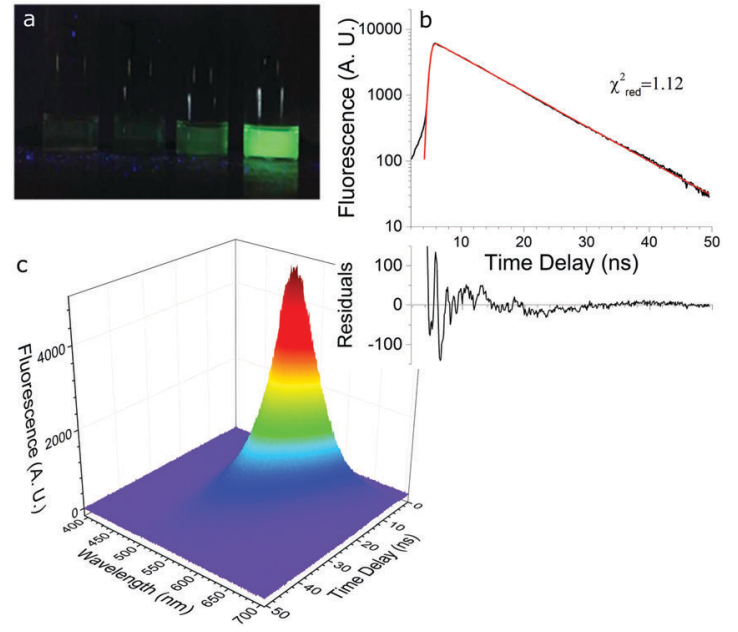

Fig. 2 (a) Vials with 1 under the four conditions for AND logic in 1:1 (v/v) $\mathrm{MeOH} / \mathrm{H}_{2} \mathrm{O}$ under $365 \mathrm{~nm}$ UV illumination (see Table 2) (b) fluorescence decay curve and residual time delay (c) $3 \mathrm{D}$ plot at $\mathrm{pH} 4$ with $60 \mu \mathrm{M} \mathrm{Fe}^{3+}$ in $1: 1(\mathrm{v} / \mathrm{v}) \mathrm{MeOH} / \mathrm{H}_{2} \mathrm{O}, \lambda_{\mathrm{ex}}=438 \mathrm{~nm}$. 
is obtained, short lifetime components of 21 ps (>97\%) and 25 ps (>99\%) were dominant for $\mathbf{1}$ and $\mathbf{3}$ with respect to the longer unquenched components, respectively. The longer component corresponds to the intrinsic lifetime of the naphthalimide fluorophore, while the shorter lifetime results when an ICT/PET from the ferrocene moiety and/or the tertiary amine to the excited state fluorophore is operational. On both oxidation and protonation, the deactivation of the PET emission quenching channels provides a single fluorescence lifetime of $8.5 \mathrm{~ns}$ and $7.3 \mathrm{~ns}$ for $\mathbf{1}$ and 3 , respectively (Fig. $2 \mathrm{~b}$ and Fig. S20, ESI $\dagger$ ). ${ }^{27}$

Further information on the photophysical behaviour of the excited naphthalimides was sought via femtosecond transient absorption studies. Firstly, studies on ferrocene-free aminepiperazine 5 (Fig. 3) showed that immediately after excitation $(<1 \mathrm{ps})$ a major charge density shift occurs within the chromophore (ground state bleaching at $450 \mathrm{~nm}$, stimulated emission centred at $540 \mathrm{~nm}$ and positive absorption at $420-450 \mathrm{~nm}$ and $650-750 \mathrm{~nm}$ ) testifying to the ICT character of the chromophore. ${ }^{28}$ The transient signals rapidly evolve with time $(\sim 50 \mathrm{ps})$, which is ascribed to a rapid electron transfer from the nitrogen atom of the piperazine group bearing a methyl group.

The presence of the ferrocene moiety on the aminonaphthalimide chromophore in $\mathbf{3}$ leads to an increase in the transient signal recovery rate $(\sim 5 \mathrm{ps}$, Fig. 4$)$ with respect to 5 . The corresponding faster excited state process in 3 is attributed to a faster electron transfer from ferrocene to the neighbouring excited chromophore.

In the case of $\mathbf{1}$, relaxation of the stimulated emission occurs with a time constant of $20 \mathrm{ps}$, which characterises the photoinduced electron transfer rate, and ground state bleaching recovery with $40 \mathrm{ps}$. This time constant can be related to back electron transfer regenerating the initial ground state. Absence of the transient absorption band at $420-450 \mathrm{~nm}$ can be understood by comparison of the tertiary amine electron donor/ proton acceptor in $\mathbf{1}$ with the methylpiperazine of $\mathbf{3}$ and $\mathbf{5}$ (Fig. 5). Indeed, it was previously suggested that a difference in behaviour between piperazine and alkylamine substituents is anticipated based on greater steric encumbrance in the case of

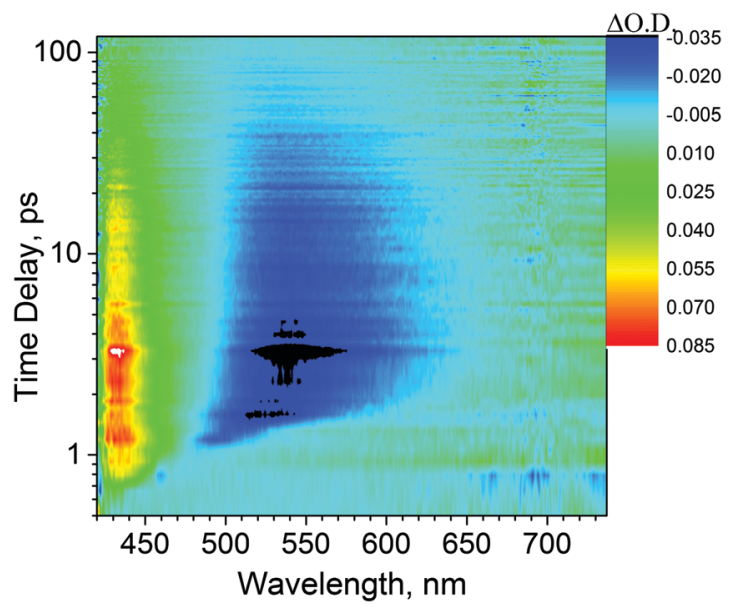

Fig. 3 Transient absorption map of 5 in acetonitrile $\left(\lambda_{\mathrm{exc}}=400 \mathrm{~nm}\right)$.

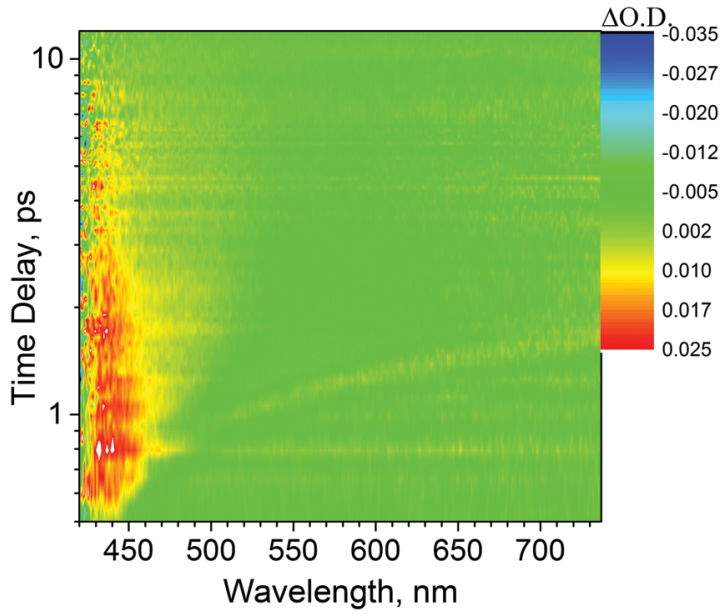

Fig. 4 Transient absorption map of 3 in acetonitrile $\left(\lambda_{\mathrm{exc}}=400 \mathrm{~nm}\right)$.

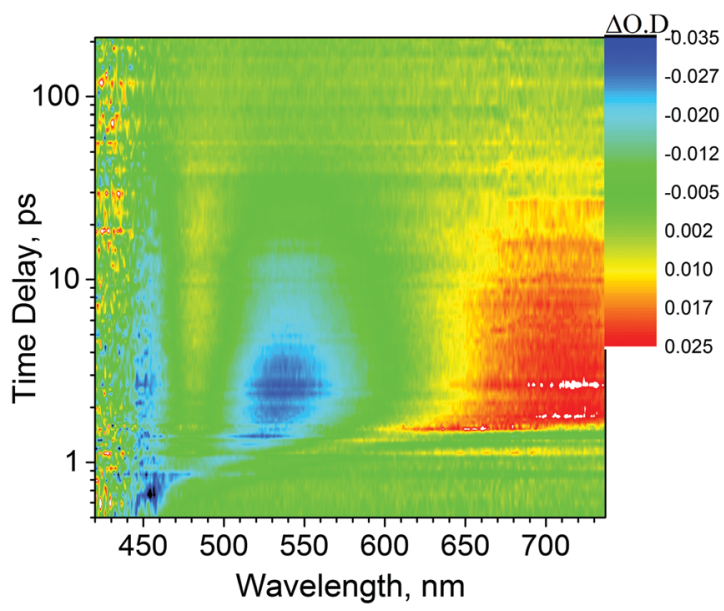

Fig. 5 Transient absorption map of 1 in acetonitrile $\left(\lambda_{\text {exc }}=400 \mathrm{~nm}\right)$.

the former, leading to an inherent enhanced twisting in the ground state, which results in a more efficient twisted ICT state. ${ }^{22}$ Both $\mathbf{1}$ and $\mathbf{5}$ exhibit a slower initial PET compared to 3, which has the ferrocene electron donor in closer proximity to the naphthalimide fluorophore.

\section{Conclusions}

In summary, we have designed and synthesised two novel 'Pourbaix sensors' based on a naphthalimide fluorophore according to a 'fluorophore-spacer ${ }_{1}$-receptor-spacer ${ }_{2}$-electrondonor' design. The molecules respond to redox potential and $\mathrm{pH}$ in accordance to two-input AND logic by a fluorescence signal. Protonation of the tertiary amine and oxidation of the ferrocene moieties prevents intramolecular charge transfer and photoinduced electron transfer resulting in a four-fold fluorescence enhancement in mixed aqueous methanol and methanol solutions. Time-resolved spectroscopic measurements confirm the efficient electron transfer processes towards the excited ICT chromophore on the tens of picosecond timescale involving ferrocene 
as well as amines, as anticipated from estimated thermodynamic driving forces. Although $\mathrm{Fe}^{3+}$ is used as the oxidant and methanesulfonic acid as the proton source, in principle, other oxidants and acids with suitable properties should give a similar output. Our results contribute to the emerging number of intelligent molecular and supramolecular devices responsive to oxidants and $\mathrm{pH}^{11,29,30}$ We are currently exploring the use of naphthalimide-based 'Pourbaix sensors' for molecular biosensing and environmental diagnostic applications.

\section{Experimental}

\section{Instrumentation}

${ }^{1} \mathrm{H}$ and ${ }^{13} \mathrm{C}$ NMR spectra were collected at $298 \mathrm{~K}$ on a Bruker Avance III HD NMR spectrometer with a multinuclear $5 \mathrm{~mm}$ PABBO probe operating at 500.13 $\mathrm{MHz}$ and $125.76 \mathrm{MHz}$ for ${ }^{1} \mathrm{H}$ and ${ }^{13} \mathrm{C}$, respectively. Samples were measured in $\mathrm{CDCl}_{3}(0.03 \%$ $\mathrm{v} / \mathrm{v}$ TMS $)$, acetone- $d_{6}(0.03 \% \mathrm{v} / \mathrm{v}$ TMS $)$ or MeOD- $d_{4}(0.03 \% \mathrm{v} / \mathrm{v}$ TMS). Melting points were measured on a Stuart SMP11 melting point apparatus and are uncorrected. Infrared (IR) spectra were recorded as $\mathrm{KBr}$ discs, neat films on $\mathrm{NaCl}$ plates or in a solution cell with a Shimadzu IR Affinity-1 spectrophotometer calibrated at $1601 \mathrm{~cm}^{-1}$ using polystyrene. $\mathrm{pH}$ measurements were performed using a $\mathrm{pH}$ meter calibrated with standard buffer solutions at $\mathrm{pH} 4.00$ and 7.00. UV-visible absorption spectra and steady-state fluorescence spectra were recorded on a Jasco V-650 spectrophotometer and Jasco FP-8300 spectrofluorimeter using $1 \mathrm{~cm}$ quartz cuvettes. The time-resolved luminescence set-up (Fig. S18, ESI $\dagger$ ) used a frequency tripled Nd:YAG amplified laser system (30 ps, 30 mJ@1064 nm, $20 \mathrm{~Hz}$, Ekspla model PL 2143) output with an optical parametric generator (Ekspla model PG 401) with tunable excitation pulses in the range 410-2300 $\mathrm{nm}$. The subpicosecond time scale set-up was based on a femtosecond $1 \mathrm{kHz}$ Ti:sapphire system (Fig. S19, ESI $\dagger$ ). HRMS spectra were conducted by Medac Ltd.

\section{Synthetic procedures}

Synthesis of 1. 4- $N$-Methylethylenediamine-1,8-methylnaphthalimide (220 mg, $0.77 \mathrm{mmol}$ ) was dissolved in $10 \mathrm{~mL}$ of dry 1,2-dichloroethane with $170 \mathrm{mg}(0.79 \mathrm{mmol})$ of ferrocenecarboxaldehyde, $220 \mathrm{mg}$ ( $1.0 \mathrm{mmol})$ of sodium triacetoxyborohydride and $0.21 \mathrm{ml}(1.5 \mathrm{mmol})$ of triethylamine in the dark at room temperature for 6 days. The reaction was monitored by TLC. The product $R_{\mathrm{f}}$ (methanol) is 0.46 . The reaction mixture was diluted with 1,2-dichloroethane and washed with $10 \%$ aqueous $\mathrm{NaHCO}_{3}$. The organic phase was dried over anhydrous magnesium sulphate, filtered and the solvent removed on a rotary evaporator. The crude brown oil was purified by column chromatography on silica gel using methanol as the eluent and recrystallised from ethyl acetate to yield $75 \mathrm{mg}$ of pure product 1 (20\% yield). M.p. $133-136{ }^{\circ} \mathrm{C} ;{ }^{1} \mathrm{H}$ NMR (500 MHz, $\mathrm{CDCl}_{3}$, ppm): $\delta_{\mathrm{H}} 8.59$ (d, $\left.J=7.3 \mathrm{~Hz}, 1 \mathrm{H}\right), 8.45(\mathrm{~d}, J=8.4 \mathrm{~Hz}, 1 \mathrm{H}), 7.97$ (d, $J=8.5 \mathrm{~Hz}, 1 \mathrm{H}), 7.60(\mathrm{~m}, 1 \mathrm{H}), 6.62(\mathrm{~d}, J=8.4 \mathrm{~Hz}, 1 \mathrm{H}), 6.15$ $(\mathrm{s}, 1 \mathrm{H}), 4.22(\mathrm{t}, J=1.8 \mathrm{~Hz}, 2 \mathrm{H}), 4.17(\mathrm{t}, J=1.8 \mathrm{~Hz}, 2 \mathrm{H}), 4.12(\mathrm{~s}, 5 \mathrm{H})$, $3.55(\mathrm{~s}, 3 \mathrm{H}), 3.50(\mathrm{~s}, 2 \mathrm{H}), 3.30(\mathrm{~m}, 2 \mathrm{H}), 2.77(\mathrm{t}, J=5.8 \mathrm{~Hz}, 2 \mathrm{H}), 2.29$ (s, 3H); ${ }^{13} \mathrm{C}$ NMR $\left(126 \mathrm{MHz}, \mathrm{CDCl}_{3}, \mathrm{ppm}\right): \delta_{\mathrm{C}} 165.1,164.5,149.7$, 134.6, 131.0, 129.7, 126.5, 124.5, 122.9, 120.4, 109.9, 104.4, 83.2, $70.0,68.6,68.3,57.1,53.3,41.6,40.0,26.8 ; \nu_{\max }\left(\mathrm{NaCl} / \mathrm{cm}^{-1}\right)$ : 3381, 3092, 2941-2799, 1682, 1643, 1582, 1418, 1533, 1396, 1362 , 1281, 1242, 1188, 1105, 1045 1026, 822; HRMS (ESI TOF) $\mathrm{m} / \mathrm{z}$ calculated $\mathrm{C}_{27} \mathrm{H}_{28} \mathrm{~N}_{3} \mathrm{O}_{2} \mathrm{Fe}[\mathrm{M}+\mathrm{H}]^{+}$482.1531, found 482.1527.

Synthesis of 2. 4- $\mathrm{N}$-Methylethylenediamine-1,8-butylnaphthalimide ( $97 \mathrm{mg}, 0.30 \mathrm{mmol}$ ) and ferrocenecarboxaldehyde $(70 \mathrm{mg}$, $0.33 \mathrm{mmol}$ ) were dissolved in $6 \mathrm{~mL}$ of dry 1,2-dichloroethane and stirred at room temperature with sodium triacetoxyborohydride (260 mg, $1.2 \mathrm{mmol}$ ) and $3 \AA$ molecular sieves in the dark for three days. The reaction mixture was diluted with dichloromethane, washed twice with saturated $\mathrm{NaHCO}_{3}(2 \times 25 \mathrm{~mL})$ and once with distilled water $(25 \mathrm{~mL})$. The organic phase was dried over anhydrous sodium sulphate, filtered, and the solvent removed on a rotary evaporator. The crude product was precipitated from diethyl ether to yield $20 \mathrm{mg}$ of orange solid $2(10 \%$ yield). M.p. $118-120{ }^{\circ} \mathrm{C} ;{ }^{1} \mathrm{H}$ NMR $\left(500 \mathrm{MHz}, \mathrm{CDCl}_{3}, \mathrm{ppm}\right): \delta_{\mathrm{H}} 8.57$ $(\mathrm{d}, J=7.2 \mathrm{~Hz}, 1 \mathrm{H}), 8.43(\mathrm{~d}, J=8.4 \mathrm{~Hz}, 1 \mathrm{H}), 7.99(\mathrm{~d}, J=8.3 \mathrm{~Hz}, 1 \mathrm{H})$, $7.58(\mathrm{~m}, 1 \mathrm{H}), 6.61$ (d, $J=8.4 \mathrm{~Hz}, 1 \mathrm{H}), 6.14$ (s, 1H, NH), 4.21-4.12 $\left(\mathrm{m}, 11 \mathrm{H}, \mathrm{FeCp}_{2}\right), 3.50(\mathrm{~s}, 2 \mathrm{H}), 3.30(\mathrm{~m}, 2 \mathrm{H}), 2.75(\mathrm{t}, J=5.7 \mathrm{~Hz}, 2 \mathrm{H})$, $2.29(\mathrm{~s}, 3 \mathrm{H}), 1.71$ (quintet, $J=7.3 \mathrm{~Hz}, 2 \mathrm{H}$ ), 1.45 (sextet, $J=7.3 \mathrm{~Hz}$, $2 \mathrm{H}), 0.97$ (t, $J=7.3 \mathrm{~Hz}, 3 \mathrm{H}) ;{ }^{13} \mathrm{C} \mathrm{NMR}\left(126 \mathrm{MHz}, \mathrm{CDCl}_{3}, \mathrm{ppm}\right)$ : $\delta_{\mathrm{C}} 164.8,164.2,149.6,134.5,131.0,129.8,126.4,124.5$, 123.1, 120.4, 110.0, 104.4, 83.1, 70.0, 68.6, 68.3, 57.1, 53.4, 41.6, 40.0, 39.9, 30.3, 20.5, 13.9; IR (solvent cell, $\mathrm{cm}^{-1}$ ): 3619, 3015, 2974, 2893, 1684, 1636, 1584, 1533, 1506, 1456, 1395, 1362, 1240, 1047; HRMS (ESI TOF) $\mathrm{m} / z$ calculated $\mathrm{C}_{30} \mathrm{H}_{33} \mathrm{~N}_{3} \mathrm{O}_{2} \mathrm{Fe}$ $[\mathrm{M}+\mathrm{H}]^{+}$542.2000, found 542.2005.

\section{Acknowledgements}

This work was supported by the University of Malta and ERDF grant 309CT 3097/2013 "Strengthening of the Organic, Inorganic, Physical Chemistry Facilities". Prof. Robert M. Borg is acknowledged for assistance with the acquisition of the NMR spectra. The Embassy of France to Malta, the CNRS, ANR FOSET and the MCST (Malta Council for Science and Technology) are acknowledged for financial aid. The Ministry for the Economy, Investment and Small Business is thanked for the 2014 Malta Science Innovation Award.

\section{Notes and references}

1 A. P. de Silva, Molecular Logic-based Computation, The Royal Society of Chemistry, Cambridge, UK, 2013.

2 (a) P. Yan, M. W. Holman, P. Robustelli, A. Chowdhury, F. I. Ishak and D. M. Adams, J. Phys. Chem. B, 2005, 109, 130; (b) M. B. J. Roeffaers, G. De Cremer, H. Uji-i, B. Muls, B. F. Sels, P. A. Jacobs, F. C. De Schryver, D. E. De Vos and J. Hofkens, Proc. Natl. Acad. Sci. U. S. A., 2007, 104, 12603.

3 (a) T. J. Dale and J. Rebek, J. Am. Chem. Soc., 2006, 128, 4500; (b) S. Bencic-Nagale, T. Sternfeld and D. R. Walt, J. Am. Chem. Soc., 2006, 128, 5041.

4 J. K. Tusa and H. He, J. Mater. Chem., 2005, 15, 2640. 
5 X. Sun and T. D. James, Chem. Rev., 2015, 115, 8001.

6 A. P. de Silva, T. S. Moody and G. D. Wright, Analyst, 2009, 134, 2385.

7 A. P. de Silva, T. P. Vance, M. E. S. West and G. D. Wright, Org. Biomol. Chem., 2008, 6, 2468.

8 (a) A. P. de Silva, Chem. - Asian J., 2011, 6, 750; (b) J. Andréasson and U. Pischel, Chem. Soc. Rev., 2015, 44, 1053; (c) G. de Ruiter and M. E. van der Boom, Acc. Chem. Res., 2011, 44, 563; (d) K. Szacilowski, Chem. Rev., 2008, 108, 3481; (e) N. D. McClenaghan and A. P. de Silva, Chem. - Eur. J., 2004, 10, 574; $(f)$ N. I. Georgiev, A. R. Sakr and V. B. Bojinov, Sens. Actuators, B, 2015, 221, 625; (g) Y. Ha, D. P. Murale, C. Yun, S. T. Manjare, H. Kim, J. Kwak, Y. Sup Lee and D. G. Churchill, Chem. Commun., 2015, 51, 6357; (h) D. Canevet, M. Salle, G. Zhang, D. Zhang and D. Zhu, Chem. Commun., 2009, 2245.

9 (a) A. J. M. Huxley, M. Schroeder, H. Q. N. Gunaratne and A. P. de Silva, Angew. Chem., Int. Ed., 2014, 53, 3622; (b) A. E. Keirstead, J. W. Bridgewater, Y. Terazono, G. Kodis, S. Straight, P. A. Liddell, A. L. Moore, T. A. Moore and D. Gust, J. Am. Chem. Soc., 2010, 132, 6588.

10 (a) D. C. Magri, M. Camilleri Fava and C. J. Mallia, Chem. Commun., 2014, 50, 1009; (b) T. J. Farrugia and D. C. Magri, New J. Chem., 2013, 37, 148; (c) D. C. Magri, New J. Chem., 2009, 33, 457.

11 D. C. Magri, Analyst, 2015, 140, 7487.

12 J. C. Spiteri, J. S. Schembri and D. C. Magri, New J. Chem., 2015, 39, 3349.

13 (a) A. P. de Silva, H. Q. N. Gunaratne, J. L. Habib-Jiwan, C. P. McCoy, T. E. Rice and J. P. Soumillion, Angew. Chem., Int. Ed., 1995, 107, 1728; (b) Y. Qin Gao and R. A. Marcus, J. Phys. Chem. A, 2002, 106, 1956.

14 (a) J. Qi, D. Liu, X. Liu, S. Guan, F. Shi, H. Chang, H. He and G. Yang, Anal. Chem., 2015, 87, 5897; (b) C. Nicosia, S. O. Krabbenborg, D. N. Reinhoudt and J. Huskens, Supramol. Chem., 2013, 25, 756; (c) S. Trupp, P. Hoffmann, T. Henkel and G. J. Mohr, Org. Biomol. Chem., 2008, 6, 4319.

15 M. Pourbaix, Atlas of Electrochemical Equilibria in Aqueous Solutions, Pergamon Press, Oxford, UK, 1966.

16 (a) X. Liu, H. Spikes and J. S. S. Wong, Corros. Sci., 2014, 87, 118; (b) A. Augustyniak, J. Tsavalas and W. Ming, ACS Appl. Mater. Interfaces, 2009, 1, 2618.

17 I. Johnson and M. T. Z. Spence, The Molecular Probes Handbook: A Guide to Fluorescent Probes and Labeling Technologies, Life Technologies Corporation, USA, 11th edn, 2010.

18 D. C. Magri and C. J. Mallia, in Supramolecular Systems in Biomedical Fields, ed. H.-J. Schneider, Royal Society of Chemistry, Cambridge, UK, 2013, ch. 3, p. 38.

19 G. Gellerman, Lett. Drug Des. Discovery, 2016, 13, 47.
20 (a) M. Cai, K. Zhu, Y. Qiu, X. Liu, Y. Chen and X. Luo, Colloids Surf., B, 2014, 116, 424; (b) W. Chen, P. Zhong, F. Meng, R. Cheng, C. Deng, J. Feijen and Z. Zhong, J. Controlled Release, 2013, 169, 171; (c) R. Cheng, F. Meng, C. Deng, H.-A. Klok and Z. Zhong, Biomaterials, 2013, 34, 3647.

21 S. Erbas-Cakmak, F. Pir Cakmak, S. Demirel Topel, T. Bilal Uya and E. U. Akkaya, Chem. Commun., 2015, 51, 12258.

22 S. Zheng, P. L. M. Lynch, T. E. Rice, T. S. Moody, H. Q. N. Gunaratne and A. P. de Silva, Photochem. Photobiol. Sci., 2012, 11, 1675.

23 A. Weller, Pure Appl. Chem., 1968, 16, 115. The driving forces for PET are estimated by $\Delta G_{\mathrm{PET}}=E_{\mathrm{OX}}-E_{\mathrm{RED}}-E_{\mathrm{S}}-e^{2} / \varepsilon r$ where $E_{\mathrm{OX}}$ is the oxidation potential of ferrocene $(0.45 \mathrm{eV})$ or the tertiary amine $(1.15 \mathrm{eV})$ and $E_{\mathrm{RED}}$ is the reduction potential of naphthalimide $(-1.57 \mathrm{eV}), E_{\mathrm{S}}$ is the excited state singlet energy of naphthalimide $(2.55 \mathrm{eV})$ and $e^{2} / \varepsilon r$ is the coulombic term $(0.10 \mathrm{eV})$. Potentials are versus SCE.

24 In ref. 12 the reported excited state singlet energy of naphthalimide was reported as $3.51 \mathrm{eV}$ resulting in overestimated PET driving forces by $c a .0 .96 \mathrm{eV}$.

25 J. Gan, H. Tian, Z. Wang, K. Chen, J. Hill, P. A. Lane, M. D. Rahn, A. M. Fox and D. D. C. Bradley, J. Organomet. Chem., 2002, 645, 168. Some photophysical data for 4 in acetonitrile: $\lambda_{\mathrm{Abs}}=$ $398 \mathrm{~nm}(\log \varepsilon=4.05), \lambda_{\text {Flu }}=521 \mathrm{~nm}\left(\Phi_{\mathrm{em}}=0.0061\right)$. In acid $\lambda_{\mathrm{Abs}}=373 \mathrm{~nm}(\log \varepsilon=4.10)$ and $\lambda_{\text {Flu }}=504 \mathrm{~nm}\left(\Phi_{\mathrm{em}}=0.38\right)$.

26 M. Li, Z. Guo, W. Zhu, F. Marken and T. D. James, Chem. Commun., 2015, 51, 1293.

27 J. Gan, K. Chen, C.-P. Chang and H. Tian, Dyes Pigm., 2003, $\mathbf{5 7}, 21$. A model compound of 3 with a methylated naphthalimide and methylpiperazine was reported to have lifetimes of $9.0 \mathrm{~ns}(80.6 \%)$ and $0.21 \mathrm{~ns}(19.4 \%)$ in methanol on excited at $360 \mathrm{~nm}$.

28 (a) P. A. Panchenko, Y. V. Fedorov, O. A. Fedorov and G. Jonusauskas, Phys. Chem. Chem. Phys., 2015, 17, 22749; (b) S. R. Domingos, M. R. Panman, B. H. Bakker, F. Hartl, W. J. Buma and S. Woutersen, Chem. Commun., 2012, 48, 353.

29 (a) H. Li, J.-N. Zhang, W. Zhou, H. Zhang, Q. Zhang, D.-H. Qu and H. Tian, Org. Lett., 2013, 15, 3070; (b) D. Sub Kim, J. Chang, S. Leem, J. Su Park, P. Thordarson and J. L. Sessler, J. Am. Chem. Soc., 2015, 137, 16038; (c) N. M. Khashab, A. Trabolsi, Y. A. Lau, M. W. Ambrogio, D. C. Friedman, H. A. Khatib, J. I. Zink and J. F. Stoddart, Eur. J. Org. Chem., 2009, 1669.

30 Recent reviews: (a) J. Sun, Y. Chen and Z. Liang, Adv. Funct. Mater., 2016, 26, 2783; (b) H. Al-Kutubi, H. Reza Zafarani, L. Rassaei and K. Mathwig, Eur. Polym. J., 2016, DOI: 10.1016/j.eurpolymj.2016.04.033. 